\title{
CALIBRATION OF INPUT PARAMETER VALUES FOR AN ADVANCED MATERIAL MODEL OF SPRAYED CONCRETE
}

\author{
Martin ZÁvackÝ ${ }^{a, *}$, Juraj ChalmovskÝ ${ }^{a}$, Lumír Miča ${ }^{a}$, Petr BíleK $^{b}$ \\ a Brno University of Technology, Faculty of Civil Engineering, Institute of Geotechnics, Veveři 331/95, 602 00 \\ Brno, Czech Republic \\ ${ }^{b}$ GEOtest, a. s., Šmahova 1244/112, 62700 Brno, Czech Republic \\ * corresponding author: zavacky.m@fce.vutbr.cz
}

\begin{abstract}
The paper briefly presents an advanced material model for shotcrete involving many aspects of the actual behavior of concrete. However, the contribution is focused on determination and calibration of selected input parameter values for practical use of the model in structural analysis. Two cross sections of different geological conditions were chosen from a utility tunnel in Brno in order to obtain sprayed concrete samples. The laboratory tests conducted are described and then compared with results from numerical approximations.
\end{abstract}

KEYwORDS: Shotcrete, triaxial tests, calibration, material model, numerical analysis.

\section{INTRODUCTION}

Nowadays numerical analysis is often used for design or assessment of more and more complicated structures in Civil Engineering including Geotechnics. Thus, more advanced material models have been developed and used both for ground and structures 1 .

The Shotcrete (SC) model was developed at Graz University of Technology [2] originally for simulation of tunnel linings made from sprayed concrete. However, the model is suitable for description of concrete and cement-based materials in general. The model is used here to demonstrate a powerful and practical tool for modelling of geotechnical structures of help to professionals in Geotechnics. A brief theoretical introduction to, and description of, the input parameters calibration process illustrated by data obtained from an existing tunnel structure is the main objective of this paper.

\section{The SHotCRETE MODEL}

The shotcrete model belongs to a group of elastoplastic constitutive models involving strain hardening and softening. The following main features are involved in the SC model [2]:

- Mohr-Coulomb yield surface for a deviatoric loading and Rankine yield surface for a tensile loading regime.

- Strain hardening and softening in tension and compression.

- Regularization during the softening regimes in order to avoid mesh dependency (Figure 1).

- Increase of shotcrete stiffness and strength over time.

- Decrease of shotcrete ductility over time.

- Creep and shrinkage strains.

\section{Applichtion of the shotcrete MODEL}

Theoretical studies on the calibration of input parameters for the SC model to verify its function have already been done [3]. Alternatively, this paper presents a practical example based on a set of laboratory tests performed on shotcrete samples taken from an existing underground structure. A utility tunnel in the city of Brno was chosen for this purpose. Two varying cross-sections in different geological conditions were examined for any potential degradation of the tunnel lining using an installed geotechnical monitoring system [4].

\subsection{Description of the Site - The PRIMARY UTILITY TUNNEL IN BRNO}

The first cross-section (CS-1) in Figure 2 is located near shaft Š13A under Leitnerova Street in a soil environment represented by Neogene clay with occasional thin interlayers of sandy sediments containing water. The thickness of the tunnel lining was measured as $30 \mathrm{~cm}$ and the lining was installed sequentially in three layers of sprayed concrete. The second cross-section investigated, (CS-2) in Figure 2 is situated near shaft Š12 under Hybešova Street. There, the rock mass is formed by Devonian sandstones and conglomerates, and thus the ground environment is considered as having a hard rock condition. Ground water inflow into the tunnel is also significant there. Thickness of the lining was measured as $20 \mathrm{~cm}$ and concrete was sprayed at once in whole thickness.

The input parameters for the SC model from each locality should be obtained from results of laboratory tests and numerical simulations described in the following sections. The process of the calibration is focused on only part of a wide spectrum of involved parameters, particularly on strain hardening and soft- 


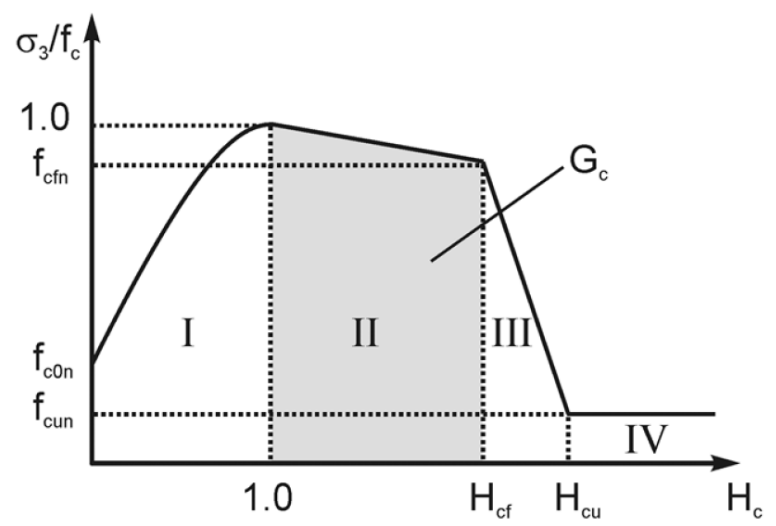

FiguRE 1. Normalized stress strain curve in compression (taken from [2]).

ening in triaxial load conditions. The small amount of material for testing and requirements for the next intended numerical analysis of the whole structure were the reasons behind selection of the properties analysed.

\subsection{LABORATORY TESTS}

Shotcrete from the lining of the utility tunnels was obtained during installation of geotechnical monitoring sensors in large drill cores with a diameter of $23 \mathrm{~cm}$. Smaller cylindrical samples with diameters of $38 \mathrm{~mm}$ and $55 \mathrm{~mm}$ were prepared by core drilling for laboratory testing later on. A set of experiments was carried out on dry concrete samples from each cross-section: splitting tensile tests, uniaxial compression and triaxial compression tests. The results are listed in Table 1 and Table 2

Dry unit weight was determined at first by measuring the dimensions and weight of samples. Three samples with diameter $55 \mathrm{~mm}$ and L/d ratio 1.0 were used for the splitting tensile test to determine tensile strength of the material [5]. The load was applied with a rate of $190 \mathrm{~N} / \mathrm{s}$. Dimensions of $38 \mathrm{~mm}$ in diameter and L/d ratio 2.0 were used in samples for the uniaxial and triaxial compression tests. Axial load was controlled by deformation through LVDT sensors with rate $0.5 \mu \mathrm{m} / \mathrm{s}$ in both cases. The Hoek-Brown pressure cell was used to induce radial pressure during triaxial tests. The possibility of monitoring after failure behaviour of the material was achieved by the deformation control. A relatively slow rate of loading was applied to meet the ductile mode of failure to prevent the brittle one. Results from one uniaxial and three triaxial compression tests with different radial pressures were considered as representative for one cross-section examined.

\subsection{Calibration of the material model}

Determination of input parameters related to the strain hardening during loading is presented in this section. Input parameters governing the strain hardening are listed in Table 3.
The uniaxial tensile strength $f_{t, 28}$ was derived from the performed splitting tensile tests. The parameter $a$ governing the shotcrete ductility and the maximum friction angle $\varphi_{\max }$ were derived from a series of triaxial tests. For determination of the remaining parameters, the uniaxial test was used. Calibration was performed on a stress point level using SoilTestLab in the Plaxis 2D 2016 software. The final model parameters for both cross sections are listed in Table 4 Measured and predicted stress strain curves are displayed in Figure 4 (CS-1) and Figure 5 (CS-2).

\subsection{Strain SOFtening}

Softening - post-failure reduction of stress with increasing strain is an important part of the actual behaviour of a sprayed concrete. However, prior to reaching the peak strength and during softening, the assumption of a homogeneous stress distribution ceases to be effective because shear bands and transverse tensile cracks occur in a sample. The strain softening rate further depends on the size of sample [6]. Thus, to obtain the softening parameters under the pressure load defined in Table 5 it is necessary to assemble a 3D model of the laboratory test with real sample dimensions and boundary conditions.

Calibration is presented only for the case of the CS-2 profile and was performed for triaxial tests with confining pressures of 2,4 and $8 \mathrm{MPa}$, respectively. For measured and predicted stress - strain curves are displayed in Figure 6. Output from the mathematical $3 \mathrm{D}$ model of the laboratory test is presented for the test with a confining pressure of $4 \mathrm{MPa}$ and a vertical deformation of $3 \mathrm{~mm}$ (Figure 3 ). Concentration of shear strains in thin zone ("shear band") inside the sample is clearly visible. The material above and below the shear zone is in unloading mode, and there are no plastic or failure points. The incidence of diagonal shear cracks was also observed in the laboratory tests presented in this paper (Figure 7).

\section{AnAlysis OF ResUlts}

\subsection{STRAIN HARDENING}

Certain variations between the properties of concrete from different cross-sections of the tunnel can be recognized from data in Table 1 Higher dry unit weight with smaller standard deviation was detected in CS-2 in comparison with CS-1. The lower variation of this parameter in CS-2 can be explained by construction of the lining in one layer of shotcrete. However, higher performance of other mechanical parameters is observed in CS-1. This fact can be explained by a higher attack of ground water on the structure in CS-2 and consequently higher degradation of the concrete.

The following aspects of actual shotcrete behaviour are correctly predicted by the numerical simulations:

- A nonlinear stiffness decrease during strain hardening (before reaching peak strength). 

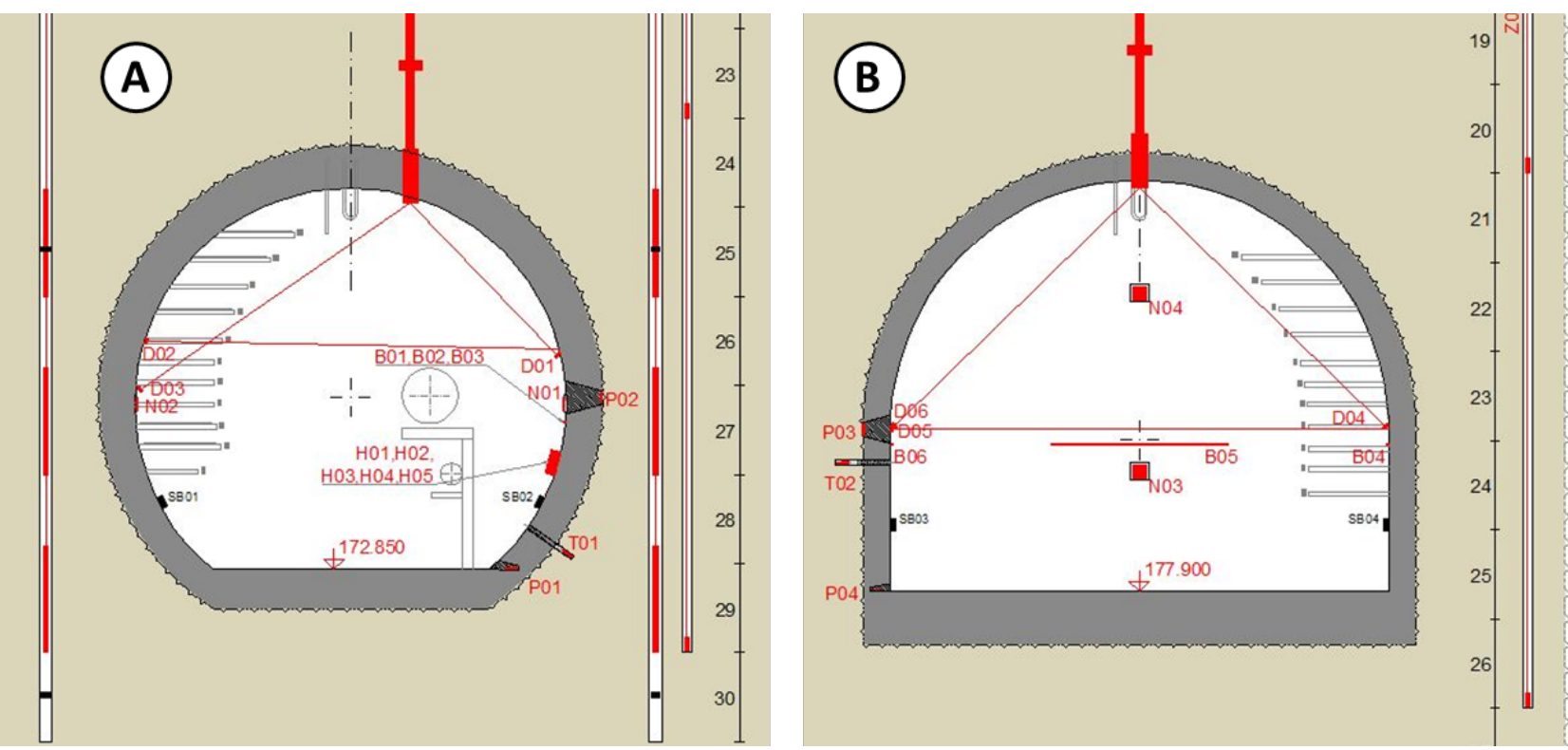

Figure 2. Cross section of the utility tunnel; Left - in soft soil conditions; Right - in hard rock conditions [4].

\begin{tabular}{llll}
\hline Parameter & Units & CS-1 & CS-2 \\
\hline Dry unit weight & $\mathrm{kg} / \mathrm{m}^{3}$ & 2161 & 2169 \\
\hline Std & $\mathrm{kg} / \mathrm{m}^{3}$ & \pm 37 & \pm 19 \\
\hline Tensile strength & $\mathrm{MPa}$ & 3.76 & 2.40 \\
\hline Std & $\mathrm{MPa}$ & \pm 0.12 & \pm 0.44 \\
\hline Uniaxial compressive strength & $\mathrm{MPa}$ & 44.0 & 35.9 \\
\hline
\end{tabular}

TABLE 1. Properties of the concrete obtained by laboratory tests.

\begin{tabular}{lll}
\hline Cell pressure & CS-1 & CS-2 \\
\hline 2.0 & 56.0 & 45.9 \\
\hline 4.0 & 63.5 & 53.4 \\
\hline 8.0 & 84.2 & 66.2 \\
\hline
\end{tabular}

TABle 2. Peak axial stresses in triaxial tests $[\mathrm{MPa}]$.

\begin{tabular}{ll}
\hline Parameter & Description \\
\hline $\mathrm{E}_{28}$ & Young's modulus of cured shotcrete \\
\hline$\nu$ & Poisson's ratio \\
\hline $\mathrm{f}_{c, 28}$ & Uniaxial compressive strength of cured shotcrete \\
\hline $\mathrm{f}_{t, 28}$ & Uniaxial tensile strength of cured shotcrete \\
\hline $\mathrm{f}_{c 0 n}$ & Normalized initially mobilized strength \\
\hline$\varepsilon_{c p} p$ & Uniaxial plastic failure strain \\
\hline $\mathrm{a}$ & Parameter governing increase of $\varepsilon_{c p}$ with mean stress $\mathrm{p}$ \\
\hline$\varphi_{\max }$ & Maximum friction angle \\
\hline
\end{tabular}

TABLE 3. Input parameters related to strain hardening. 

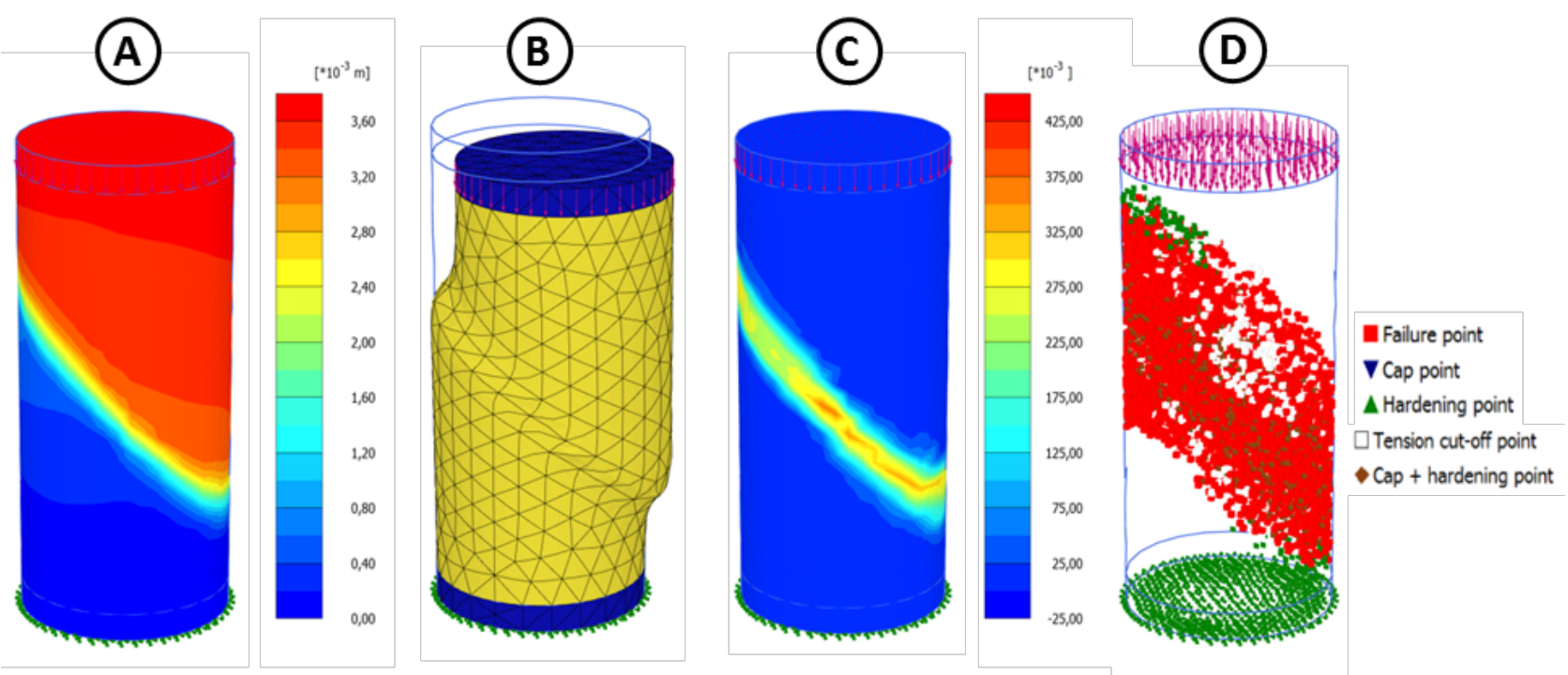

FiguRE 3. Simulation of triaxial test with confining pressure $4 \mathrm{MPa}$, vertical deformation $3 \mathrm{~mm}$ - isosurfaces of total deformations (A); deformed elements mesh $-2 \times$ enlarged (B); isosurfaces of shear strain (C); failure points and points of plasticity (D).

\begin{tabular}{llll}
\hline Parameter & Units & CS-1 & CS-2 \\
\hline $\mathrm{E}_{28}$ & $\mathrm{MPa}$ & 13,500 & 15,500 \\
\hline$\nu$ & - & 0.2 & 0.2 \\
\hline $\mathrm{f}_{c, 28}$ & $\mathrm{MPa}$ & 45 & 35 \\
\hline $\mathrm{f}_{t, 28}$ & $\mathrm{MPa}$ & 3.4 & 2.4 \\
\hline $\mathrm{f}_{c 0 n}$ & $\mathrm{MPa}$ & 0 & 0 \\
\hline$\varepsilon_{c p} p$ & - & 0.0015 & 0.0016 \\
\hline $\mathrm{a}$ & - & 18 & 24 \\
\hline$\varphi_{\max }$ & $\circ$ & 40 & 39 \\
\hline
\end{tabular}

TABLE 4. Sets of calibrated parameters.

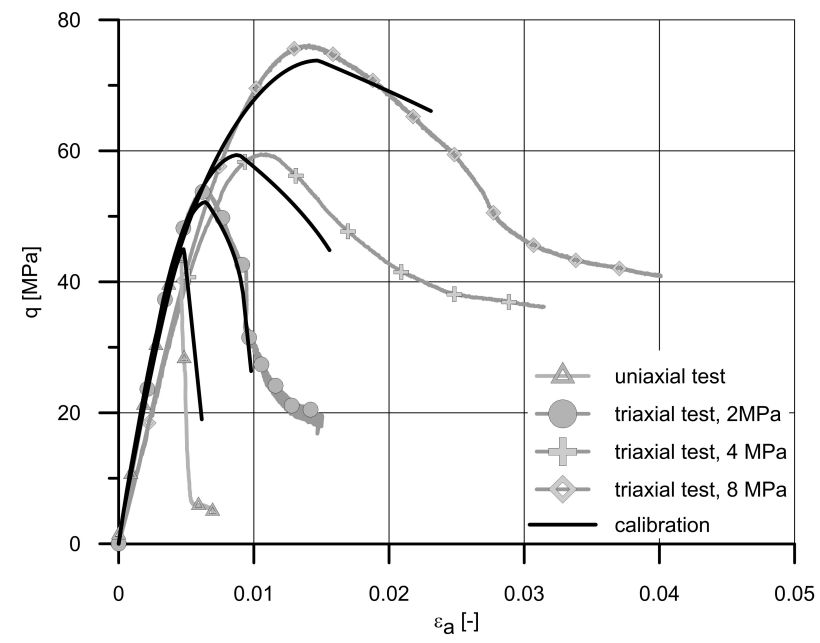

FiguRE 4. Measured and predicted stress - strain curves for profile CS-1.

- A compressive strength and ductility increase with increasing confining pressure in triaxial loading conditions.

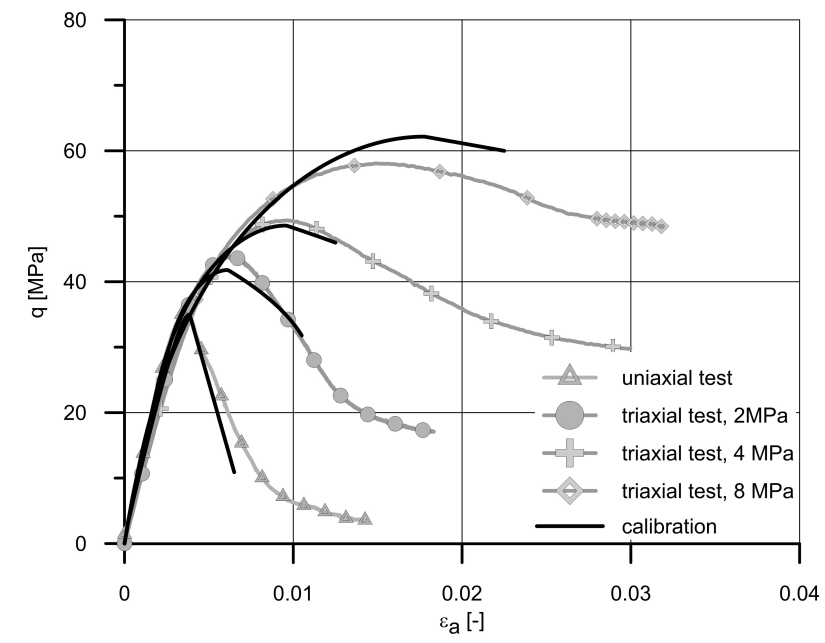

Figure 5. Measured and predicted stress - strain curves for profile CS-2.

- A decrease in the rate of strain softening with increasing confining pressure. However, it is possible 


\begin{tabular}{ll}
\hline Parameter & Description \\
\hline $\mathrm{f}_{c f n}$ & Normalized failure strength \\
\hline $\mathrm{f}_{c u n}$ & Normalized residual strength \\
\hline $\mathrm{G}_{c, 28}$ & Fracture energy of cured concrete in compression \\
\hline
\end{tabular}

TABLE 5. Input parameters for strain softening in compression.

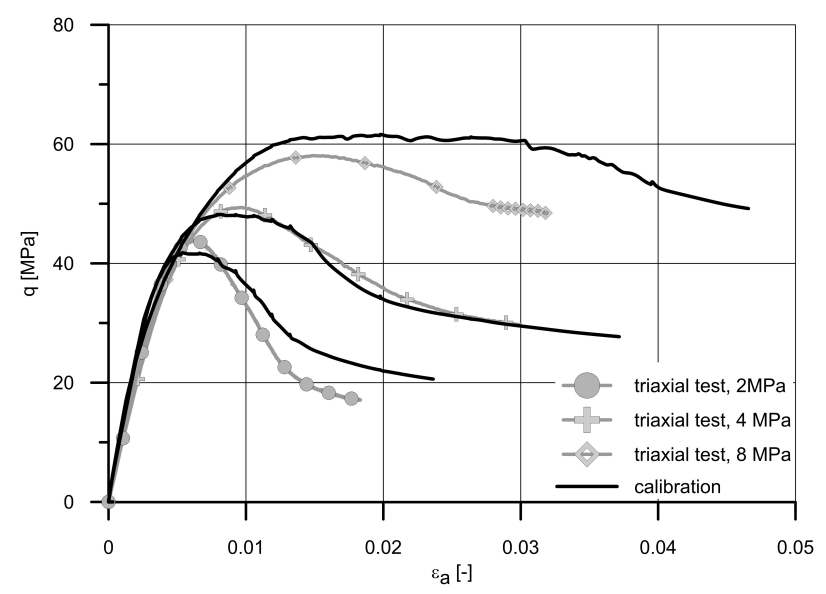

Figure 6. Measured and predicted stress-strain curves with strain softening in after failure part from CS-2 profile.
(A)

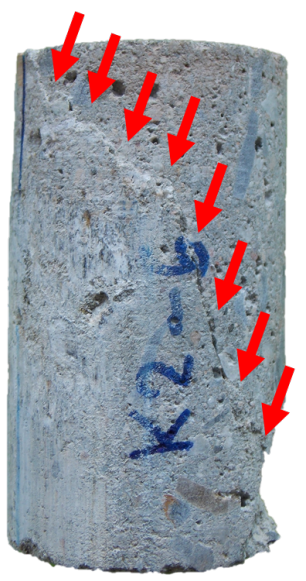

(B)

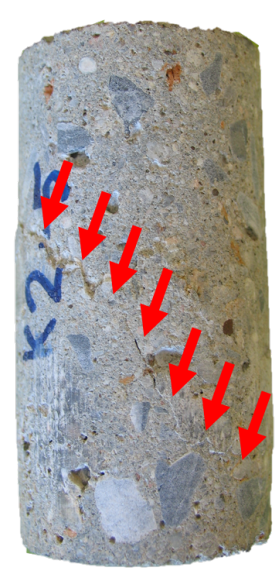

FiguRE 7. Failure of samples in triaxial loading conditions - confining pressure of $4 \mathrm{MPa}(\mathrm{A})$; confining pressure of $8 \mathrm{MPa}(\mathrm{B})$.

to analyse this aspect only from a qualitative point of view; the quantitative prediction requires a complete 3D model.

Lower initial stiffness is observed for the tests with 4 and $8 \mathrm{MPa}$ confining pressures (CS-1). This effect can be caused by incidence of initial micro-cracks in the samples which cannot be taken into account during simulation. Predicted compressive strengths for both sections are slightly different in comparison with measured ones in the case of the test with the cell pressure of $8 \mathrm{MPa}$. This might be caused by curvature of the actual failure envelope when the SC model has carried through a linear Mohr-Coulomb failure crite- rion. Regardless of the causes, variation of concrete properties was recognized. Thus, the requirements of two different sets of input parameters for the SC model described in Table 4 is considered to be necessary in order to achieve better accordance of the numerical simulations with results from laboratory tests.

\subsection{Strain SOFTENING}

The best fit with the measurement is achieved for the test with a confining pressure of $4 \mathrm{MPa}$. Ductile behaviour is overestimated by simulation in the case of the $8 \mathrm{MPa}$ confining pressure, so the initiation of softening occurs later than in the case of the laboratory test. The predicted rate of softening at a $2 \mathrm{MPa}$ confining pressure is slightly lower than the measured one.

\section{Conclusions}

Differences in the mechanical and physical properties of the concrete were observed between the two cross-sections of the tunnel that were analysed. The variation can be explained by the different process of construction and also by different conditions of degradation caused by the ground water regime.

A reasonable match between the measured stressstrain curves and those obtained by numerical simulations was found in the part of strain hardening when the advanced SC model was used.

By combining the $3 \mathrm{D}$ mathematical model of the triaxial test and the SC material model, it is possible to predict post-failure behavior with an accuracy which is sufficient from an engineering point of view. The predicted lower softening rates for some of the tests could be caused by incidence of micro-cracks before the start of the laboratory tests. The process of strain softening and its influence on, and correct prediction in, real geotechnical structures is a subject for further research.

\section{ACKNOWLEDGEMENTS}

The research for this paper has been carried out under the project No. CZ.01.1.02/0.0/0.0/15_013/0004874 "Vytvoření partnerské kooperace mezi firmou GEOtest a regionálním výzkumným centrem AdMaS" supported by the Ministry of Industry and Trade under the "European Regional Development Fund Operational Programme Enterprise and Innovations for Competitiveness". 


\section{REFERENCES}

[1] B. Schädlich, T. Marcher, H. Schweiger, E. Saurer. Application of a novel constitutive shotcrete model to tunnelling. In ISRM Regional Symposium - EUROCK. ISRM, Vigo, 2014. DOI:10.1201/b16955-137.

[2] B. Schädlich, H. Schweiger. Numerical Methods in Geotechnical Engineering. CRC Press, London, 2014. DOI:10.1201/b17017-20

[3] R. Schütz, D. Potts, L. Zdravkovic. Advanced constitutive modelling of shotcrete: Model formulation and calibration. Computers and Geotechnics 38:834-845, 2011. DOI:10.1016/j.compgeo.2011.05.006
[4] P. Bílek, O. Pazdírek, D. Rupp. Design of control geotechnical monitoring system of primary collector in brno. In Proceeding of International Conference of Doctoral Students Juniorstav 2016. Brno University of technology, 2016.

[5] EN 12390-6 - Testing hardened concrete - Part 6: Tensile splitting strength of test specimens.

[6] D. Jansen, S. Shah. Effect of length on compressive strain softening of concrete. Journal of Engineering Mechanics 123.1:25-35, 1997. 